\title{
APLIKASI PEDULILINDUNGI MITIGASI BENCANA COVID-19 DI INDONESIA
}

\author{
Citra Eka Putri ${ }^{1}$ dan Radja Erland Hamzah ${ }^{2}$ \\ ${ }^{1,2}$ Universitas Prof. Dr. Moestopo (Beragama), Jakarta - Indonesia \\ ekaputricitra8@gmail.com
}

\begin{abstract}
In addition to adequate information about the potential for the Covid-19 disaster that has hit the world, especially Indonesia, mistakes in communicating information can cause uncertainty that worsens the situation. This study aims to analyze the disaster analysis model in the protected care application created by the government as a form of disaster mitigation in this country. This study uses a qualitative descriptive method. The object of the research is the disaster communication model in the Pedulilindung application launched by KOMINFO. The subjects of this research are parties involved in making the idea of a protected application, namely the head of the Public Relations Bureau of KOMINFO Mr. Ferdinandu Setu and also the users of the application. Methods of data collection using in-depth interviews and observations. as a result, KOMINFO conducts disaster response with a disaster communication model which includes, among others, information, communication, coordination, disaster mitigation and the media. media involvement ensures messages and information conveyed are accurate, fast and precise, targeting the use of social media in Indonesia to the fifth largest in the world, but the result is that many Indonesians are reluctant to use the application because it is not effective.
\end{abstract}

Keywords: communication, disaster, covid 19

\begin{abstract}
Abstrak
Selain informasi yang memadai tentang potensi bencana covid-19 yang melanda dunia kususnya indonesia, Kekeliruan dalam mengkomunikasikan sebuah informasi bisa menimbulkan ketidakpastian yang memperburuk situasi. Penelitian ini bertujuan untuk menganaisis model analisis bencana pada aplikasi PeduliLindungi yang diciptakan oleh pemerintah sebagai salahsatu bentuk mitigasi bencana ditanah air, Penelitian ini menggunakan metode deskriptif kualitatif. Objek penelitian adalah model komunikasi bencana pada aplikasi PeduliLindungi yang dicanangkan KOMINFO. Subjek penelitian ini adalah pihak yang terlibat dalam pembuatan ide aplikasi PeduliLindungi, yaitu kepala Biro Humas KOMINFO Bapak Ferdinandu Setu dan juga para pengguna aplikasi tersebut. Metode pengumpulan data menggunakan wawancara mendalam dan observasi. hasilnya KOMINFO melakukan tanggap bencana dengan model komunikasi bencana yang meliputi antara lain, Informasi, Komunikasi, Koordinasi, Mitigasi bencana dan media. keterlibatan media memastikan pesan dan informasi yang disampaikan akurat, cepat dan tepat, menyasar pada penggunaan media sosial di indonesia ke lima terbesar didunia, namun hasilnya masih banyak masyarakat Indonesia yang justru enggan menggunakan aplikasi tersebut dengan alasan kurang efektif.
\end{abstract}

Kata kunci: komunikasi, bencana, covid 19

\section{PENDAHULUAN}

Kehadiran UU nomor 24 tahun 2007 tentang penanggulangan bencana juga merupakan bagian dari pentingnya rencana bangsa ini untuk mempersiapkan segala potensi dalam menghadapi suatu bencana bencana. Penanggulangan bencana harus didukung oleh berbagai pendekatan baik soft power maupun hard power untuk mengurangi resiko dari bencana tersebut. Pendekatan soft power adalah dengan mempersiapkan kesigapan masyarakat melalui sosialisasi dan pemberian informasi yang akurat tentang bencana. Karena kedepannya mitigasi bukan tidak mungkin bisa menjadi public education (Rahman, 2015). Sementara hard power adalah upaya dalam 
menghadapi bencana dengan menciptakan pembangunan fisik seperti membangun sarana komunikasi, membangun tempat pengungsian sementara, mendirikan dinding beton untuk tanggul, mengeruk sungai dan lain-lain. Dalam UU, dua hal ini disebut dengan istilah mitigasi bencana.

Pada dua pendekatan inilah, komunikasi bencana amat dibutuhkan. Apalagi dikatan juga mitigasi bencana efektif dalam penangulangan konsep dan prinsip penyelamatan diri jika terjadi bencana (Rusilowati, Supriyadi, Binadja dan Mulyani, 2012). Komunikasi dalam bencana tidak saja dibutuhkan dalam kondisi darurat bencana saja, namun penting juga pada saat dan pra bencana. Mempersiapkan masyarakat di daerah rawan bencana tentu harus senantiasa dilakukan. Selain informasi yang memadai tentang potensi bencana di suatu daerah, pelatihan dan internalisasi kebiasaan menghadapi situasi bencana juga harus dilakukan secara berkelanjutkan. Tapi harus diingat, informasi berlimpah saja tidak cukup untuk menyadarkan warga atas bahayanya suatu bencana yang mengancam. Upaya kesiapsiagaan masyarakat di Indonesia terhadap bencana dinilai masih lemah, sehingga membutuhkan upaya khusus untuk menambah pengetahuan tentang mitigasi bencana (Pahleviannur, 2019). Walaupun tak ayal pencegahan bencana juga mampu terbentuk secara turun temurun di dalam lapisan masyarakat (Permana, Nasution \& Gunawijaya, 2021).

Cara untuk menyampaikan informasi juga harus dilakukan dengan tepat. Kekeliruan dalam mengkomunikasikan sebuah informasi bisa menimbulkan ketidakpastian yang malah nantinya akan memperburuk situasi. Dalam situasi ini, pendekatan komunikasi bisa menggunakan medium komunikasi digital yang sedang marak digunakan oleh masyarakat luas, melihat kondisi ini maka KOMINFO bekerjasama dengan Kementerian Kesehatan dan Kementerian Badan Usaha Milik Negara (BUMN) menciptakan mobile aplication bernama "PeduliLindungi", aplikasi yang digunakan oleh instansi pemerintah Indonesia untuk kepentingan pelacakan dan penghentian penyebaran virus Covid-19 di wilayah RI. Diharapkan aplikasi PeduliLindungi mampu melindungi masyarakat Indonesia dengan mengandalkan partisipasi masyarakat untuk saling membagikan data lokasinya saat berpergian agar penelusuran riwayat kontak dengan penderita Covid-19 dapat terus dilakukan.

Penelitian terdahulu yang digunakan untuk menunjang penelitian ini adalah yang pertama pada dengan judul "Disaster Communication Uses Field Training Exercise Simulation as an Important Aspect of Disaster Risk Reduction", dimana tujuan pada penelitian tersebut adalah untuk mengetahui model komunikasi bencana erupsi Gunung Sinabung melalui simulasi latihan lapangan untuk menguji dokumen Contingency Plan sebelum dijadikan kebijakan. Metode yang digunakan adalah deskriptif kualitatif, dengan objek penelitian komunikasi bencana erupsi Gunung Sinabung. Subjek penelitian adalah kepala pos pengamatan Sinabung, kepala BPBD, pembantu bupati, kepala dinas Komunikasi dan Informatika, wartawan, korban, dan relawan. Teknik pengumpulan data dilakukan dengan wawancara mendalam, observasi, dokumentasi, Focus Group Discussion, dan simulasi latihan lapangan. Teknik analisis data dilakukan secara kualitatif sebelum simulasi, saat simulasi, dan setelah simulasi. (Lestari, Ritonga, Rulian \& Barus, 2020).

Perbedaan dengan penelitian terdahulu model komunikasi bencana meliputi bencana erupsi gunung Sinabung dan menguji dokumen contigency plan dengan teknik analisis data melalui simulasi bencana. Sedangkan pada penelitian yang dilakukan peneliti meliputi model komunikasi bencana pada aplikasi pedulilindungi yang digunakan pemerintah sebagai salah satu mitigasi bencana Covid-19 di tanah air.

Penelitian terdahulu yang berikutnya dipublikasi pada berjudul "Komunikasi Bencana: Aspek Sistem (Koordinasi, Informasi dan Kerjasama)", pada penelitian inidigambarkan BNPB sebagai lembaga yang 
menanggulangi bencana di Indonesia, dimana dalam manajemen bencana diperlukan pendekatan yang tepat yaitu pendekatan sistem, yang akan membantu dari proses mitigasi sampai pasca bencana dapat berjalan dengan baik, karena dilaksanakan secara terintergrasi dan sinergis antar lembaga dan komponen masyarakat. Penelitian ini menganalisis aspek pada sistem bencana melalui $3 \mathrm{~K}$ koordinasi, Informasi dan Kerjasama saja tidak secara menyeluruh menganalisis model komunikasi bencananya (Budi HH, 2012), berbeda dengan penelitian yang dilakukan peneliti yaitu model komunikasi bencana menjadi bagian utama dalam analisisnya, sehingga ditemukan model komunikasi yang digunakan dalam pembuatan aplikasi PeduliLindungi dalam mitigasi bencana Covid-19 di tanah air. Dengan demikiann penelitian ini bertujuan untuk menganaisis model analisis bencana pada aplikasi PeduliLindungi.

\section{METODOLOGI PENELITIAN}

Penelitian ini menggunakan metode deskriptif kualitatif. Objek penelitian adalah model komunikasi bencana pada aplikasi PeduliLindungi sebagai salah satu mitigasi bencana Covid-19 di tanah air. Subjek penelitian ini adalah pihak yang terlibat dalam pembuatan ide aplikasi PeduliLindungi, yaitu kepala Biro Humas KOMINFO bapak Ferdinandu Setu dan juga para pengguna aplikasi tersebut. Metode pengumpulan data menggunakan wawancara mendalam dan observasi, adapun teknik analisis data kualitatif yang digunakan dalam penelitian dilakukan dengan cara: (1) pengumpulan data pada saat pra penelitian, selama penelitian, dan pasca penelitian. Pengumpulan data tersebut terkait komunikasi bencana yang terjadi di Indonesia yaitu Covid-19, dimana aplikasi PeduliLindungi diciptakan sebagai aplikasi pendukung pemerintah dalam tracking record masyarakat yang terpapar Covid-19 ditanah air, (2) Penyajian data dilakukan dengan pemilihan data yang dibutuhkan dan relevan dengan penelitian, kemudian disajikan dalam bentuk tabel atau gambar yang disajikan untuk menjelaskan dan menganalisis data kualitatif tersebut; (3) menarik kesimpulan dari data yang telah disajikan untuk menjadi interpretasi atau hasil penelitian. Penarikan kesimpulan terkait penggunaan aplikasi PeduliLindungi yang dapat dijadikan model komunikasi bencana dalam bencana nasional Covid-19 di Indonesia (Ali, 2015).

\section{HASIL DAN PEMBAHASAN Aplikasi PeduliLindungi}

Aplikasi PeduliLindungi ditetapkan melalui Keputusan Menteri Komunikasi dan Informatika Nomor 171 Tahun 2020 sebagaimana telah diubah dengan Keputusan Menteri Komunikasi dan Informatika Nomor 253 Tahun 2020 tentang Perubahan Atas Keputusan Menteri Komunikasi dan Informatika Nomor 171 Tahun 2020 tentang Penetapan Aplikasi PeduliLindungi Dalam Rangka Pelaksanaan Surveilans Kesehatan Penanganan Corona Virus Disease 2019 (Covid-19).

Sebagai aplikasi yang dipergunakan dalam pelaksanaan surveilans kesehatan oleh pemerintah dalam menangani penyebaran Covid-19, maka aplikasi PeduliLindungi ini harus terus dipertahankan karena sangat membantu masyarakat dalam upaya penelusuran (tracing), pelacakan (tracking) dan pemberian peringatan (warning dan fencing) Covid-19.

Aplikasi PeduliLindungi ini masih terus dikembangkan dengan melengkapi beragam fitur yang dapat mempermudah masyarakat di era kenormalan baru, salah satunya dengan akan ditambahkannya fitur e-passport sebagai dokumen perjalanan dalam bentuk data pengguna yang telah dinyatakan negatif tes Covid-19. Pemerintah juga akan meningkatkan aplikasi PeduliLindungi agar bisa digunakan oleh perangkat telepon non-smartphone. Sehingga nantinya aplikasi ini bisa juga digunakan oleh pengguan telepon melalui teknologi SMS.

Selainn itu pemerintah juga membuat dashboard monitoring yang digunakan untuk tracing, tracking, dan fencing. Dalam hal ini 
dashboard tracing dan tracking untuk melihat user yang pernah closed-contact dengan pasien positif. Dashboard fencing untuk melihat pergerakan orang dalam karantina mandiri. Untuk memontoring tersedia di Kementerian Kesehatan yang dapat digunakan khususnya untuk memonitor pasien dan orang yang melakukan karantina mandiri.

Melihat Indonesia merupakan negara ke lima terbesar dalam penggunaan media sosialnya, kini masyarakat tak lagi tertinggal dalam penggunaan smartphone di tanah air, banyak aplikasi yang digunakan untuk sekedar mencari informasi ataupun hiburan, ditengah pandemi Covid yang melanda Idonesia, pemerintah pun tidak tinggal diam melihat momentum tersebut, pemerintah bersama KOMINFO dan kementrian kesehatan menciptakan aplikasi yang diharapkan sebagai peluang dalam mitigasi bencana Covid-19 di Indonesia.

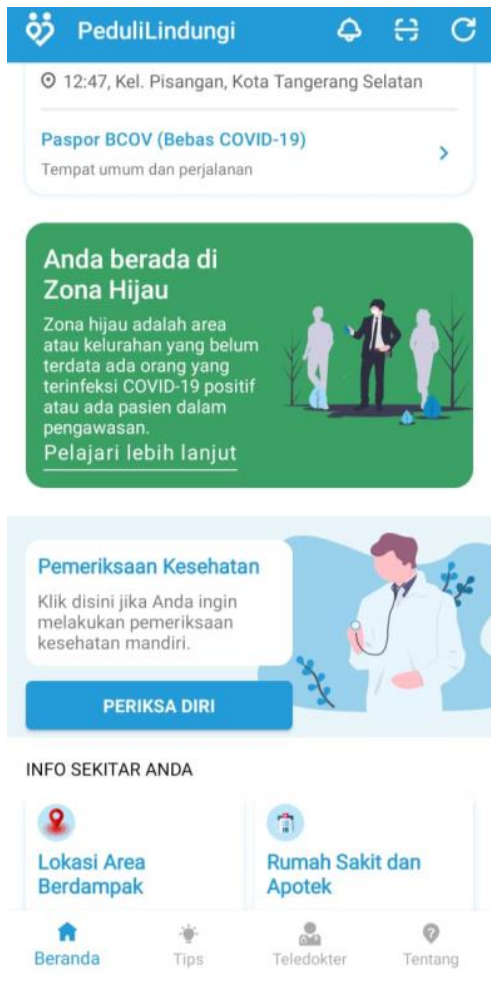

Gambar 1. Aplikasi PeduliLindungi memberikan info terkait Covid-19 dilokasi yang kita datangi
Aplikasi ini diciptakan untuk mengidentifikasi orang-orang yang pernah berada dalam jarak dekat dengan orang yang dinyatakan positif Covid-19 atau Pasien Dalam Pengawasan (PDP) dan Orang Dalam Pengawasan (ODP). Melalui aplikasi tersebut, pengguna dapat mengingat riwayat perjalanan dan dengan siapa saja dia melakukan kontak. Selain itu, aplikasi ini juga dapat memudahkan masyarakat yang tengah beraktivitas di luar rumah untuk mewaspadai kurir pembawa virus (gambar 1). Asal dengan catatan, seluruh masyarakat baik yang positif, sembuh, dalam pemantauan, maupun sehat memberikan informasi dirinya.

Adapun cara kerja aplikasi PeduliLindungi bagi masyarakat yang sudah mengunduh aplikasi ini diminta untuk mengaktifkan bluetooth pada ponselnya. Diharapkan dengan kondisi beluetooth aktif, maka secara berkala aplikasi akan melakukan identifikasi ponsel pengguna PeduliLindungi lainnya, yang berada di radius bluetooth untuk merekam lokasi dan waktu kontaknya. Mekanismenya ponsel-ponsel yang berdekatan kemudian akan saling merekan ID anonim masing-masing, data Anonim ID tersebut akan disimpan dalam rentan waktu 14 hari, sehingga apabila ada seseorang yang dinyatakan sakit oleh petugas kesehatan (bukan oleh aplikasi) dan diinput kedalam sistem database, maka sistem akan memfilter ID-ID anonim lain yang terrekam pernah melakukan kontak dengan penderita Covid-19 dalam waktu 14 hari terakhir.

Aplikasi PeduliLindungi ini diciptakan oleh pemerintah sebagai mitigasi bencana Covid-19 yang terjadi di Indonesia. Selain mampu memberikan informasi jumlah orang yang terpapar Covid per area, seperti pada gambar 2 terdapat fitur pada aplikasi PeduliLindungi juga memberikan beberapa hal penting terkait bencana Covid-19, seperti adanya fitur periksa kesehatan mandiri melalui aplikasi pihak ke tiga yang sudah disediakan dan ada beberapa tips kesehatan dalam mencegah penyebaran Covid-19 di masyarakat. 




Gambar 2. Fitur-fitur pada aplikasi PeduliLindungi

Adapun kendala yang pemerintah rasakan dalam sosialisasi penggunaan aplikasi PeduliLindungi adalah pemanfaatan aplikasi PeduliLindungi saat ini belum sepenuhnya optimal dikarenakan masih terhambatnya proses entry data orang positif Covid-19 oleh instansi terkait, dan jumlah pengguna aplikasi PeduliLindungi juga masih perlu terus ditingkatkan. Untuk itu, agar efektivitas aplikasi PeduliLindungi dapat semakin ditingkatkan maka diperlukan enforcement dari pemerintah diantaranya; pertama, mewajibkan masyarakat ASN (Aparatur Sipil Negara), pegawai BUMN untuk menggunakan izin perjalanan digital yang ada pada PeduliLindungi. Kedua, menyiapkan aparat dilapangan terkait verifikasi izin perjalanan digital pada PeduliLindungi. Ketiga, menyiapkan personil verifkator permohonan izin perjalanan. Keempat, proses pengecekan pekerja, pegawai oleh keamanan gedung untuk mengunduh dan memasang aplikasi PeduliLindungi para perangkat selular sebelum diizinkan masuk ke gedung. Kelima, proses pengecekan pengunjung mal atau daerah wisata oleh keamanan untuk mamasng aplikasi PeduliLindungi sebelum diizinkan masuk mal atau daerah wisata.

\section{Komunikasi}

Keberadaan komunikasi sebagai sebuah ilmu yang berkaitan dengan aktivitas sosial semakin disadari teramat penting. Sebagai manusia yang hidup dan berinteraksi dengan orang lain, komunikasi selalu dibutuhkan. Sejak manusia dilahirkan komunikasi telah dilakukan begitu seterusnya hingga masa akhir kehidupan manusia. Dengan demikian kita dapat mengatakan komunikasi merupakan aktivitas yang tidak bisa ditiadakan selama manusia hidup. Hal ini sejalan dengan yang dikatakan Ruben dan Steward (2013) bahwa tidak ada kegiatan yang lebih mendasar untuk 
kehidupan kita secara pribadi maupun sosial dan professional kecuali komunikasi. Lebih lanjut Ruben dan Steward mengatakan bahwa, "Kesadaran komunikasi merupakan proses yang amat mendasar, mau tidak mau menyiratkan bahwa hal itu mudah dipahami atau dikendalikan. Sebaliknya, komunikasi itu sangat kompleks dan memiliki banyak bentuk. Banyak contohnya dalam kehidupan pribadi, keluarga, masyarakat, profesional, teknologi, nasional ataupun tradisional" (Ruben dan Steward, 2013: 4).

Penegasan tentang pentingnya komunikasi dalam kehidupan manusia juga disampaikan oleh Scheidel dalam Mulyana (2007: 4) yang mengemukakan, "Bahwa kita berkomunikasi terutama untuk menyatakan dan mendukung identitas diri, untuk membangun kontak sosial dengan orang sekitar kita dan untuk mempengaruhi orang lain untuk merasa, berpikir atau berperilaku seperti yang kita inginkan. Namun menurut Sheidel tujuan dasar kita berkomunikasi adalah untuk mengendalikan lingkungan fisik dan psikologis kita". Berdasarkan penjelasan tersebut, maka komunikasi dapat dikatakan sebagai perilaku atau aktivitas manusia yang utama dalam kehidupannya di muka bumi ini. Tidak mungkin manusia tidak melakukan kontak sosial dengan orang lain dan lingkungannya. Itu semua tentu saja dilakukan dengan komunikasi.

Selain merupakan aktivitas yang mendasar dalam kehidupan manusia, komunikasi juga memiliki tujuan penting untuk menyelesaikan tugas-tugas penting bagi kebutuhan manusia serta untuk membentuk dan menciptakan hubungan dengan orang lain. Jadi komunikasi mempunyai fungsi isi, yang melibatkan pertukaran informasi yang kita perlukan untuk menyelesaikan tugas dan fungsi hubungan untuk melibatkan pertukaran informasi mengenai bagaimana hubungan kita dengan orang lain (Zimmerman dalam Mulyana 2007: 4).

Terkait dengan fungsi hubungan, komunikasi adalah jalur yang menghubungkan manusia di dunia, sarana untuk menampilkan kesan, mengekspresikan diri, mempengaruhi orang lain dan mengorbankan diri kita sendiri. Melalui komunikasilah manusia membangun hubungan dengan orang lain yang berbeda. Komunikasi adalah sarana mencapai kegiatan bersama, menghubungkan satu dengan yang lain dan alat berbagi ide. Dalam kelompok, organisasi dan masyarakat, komunikasi adalah sarana yang dapat mempertemukan kebutuhan dan tujuan kita sendiri dengan kebutuhan dan tujuan pihak lain. Di dalam organisasi yang lebih besar, masyarakat dan komunitas dunia, komunikasi menyediakan jaringan hubungan yang memungkinkan kita untuk melakukan aksi bersama, pembentukan identitas bersama dan pembangunan kepemimpinan (Ruben dan Stewart 2013: 17).

Komunikasi menjadi hal yang sangat dibutuhkan didalam situasi bencana, bagaimanapun juga komunikasi memegang peranan penting dalam proses pemberian informasi terkait yang ingin disampaikan oleh pemerintah kepada masyarakatya ditengah pandemi Covid-19, maka faktor komunikasi yang baik tadi menjadi hal yang harus diprioritaskan, pandemi Covid yang belum jelas kapan berakhir, membuat masyarakat menjadi semakin ketakutan dan khawatir, kekhawatiran dan kejenuhan tadilah yang menjadi slaah satu latar belakang Pemerintah, bersama KOMINFO dan kementerian kesehatan berinisiatif menciptakan aplikasi yang mampu memantau penyebaran Covid di masyarakat dan juga bisa memberikan info-info akurat seputar Covid -9.

Pemerintah melalui KOMINFO bekerja sama untuk mengajak masyarakat mengunduh aplikasi tersebut guna memudahkan pemerintah dalam melacak penyebaran Covid di tanah air, sosialisasi digerakan dari mulai perangkat PNS pegawai negeri sipil yang diwajibkan mengunduh aplikasi tersebut sampai kepada lapisan masyarakat luas, namun jumlah pengunduh aplikasi PeduliLindungi per $26 \mathrm{Juli}$ 2020 hanya mencapai 4.261.815. Jika dibandingkan dengan jumlah penduduk Indonesia dan jumlah pengguna smartphone maka angka pengguna aplikasi PeduliLindungi ini masih terlalu kecil. Sehingga dibutuhkan 
peran aktif masyarakat untuk bersama-sama memanfaatkan aplikasi PeduliLindungi ini. Selain itu diperlukan juga enforcement dari pemerintah untuk terus meningkatkan efektivitas dari aplikasi ini juga mendorong pihak-pihak terkait untuk dapat memaksimalkan fungsi dari aplikasi PeduliLindungi ini.

Masyarakat membutuhkan informasi secara komprehensif mengenai Covid-19 yang disampaikan dengan bahasa sederhana dan mudah dipahami oleh seluruh lapisan masyarakat melalui media massa, media online juga media sosial. Adanya komunikasi dan informasi satu pintu diperlukan untuk dijadikan referensi bagi masyarakat yang ingin mengetahui seluk beluk dan juga perkembangan dari Covid-19 ini (Setu, 2020).

\section{Komunikasi Bencana}

Istilah komunikasi bencana belum menjadi konsep popular dalam bidang komunikasi maupun bidang kebencanaan. Meski penelitian komunikasi bencana sendiri telah banyak dilakukan, namun di Indonesia kajian komunikasi terkait bencana baru banyak dilakukan setelah peristiwa bencana alam gempa dan tsunami Aceh tahun 2014. Meski demikian, kesadaran akan pentingnya komunikasi dalam penanganan bencana semakin tinggi belakangan ini. Salah satu titik penting yang menjadi perhatian terkait komunikasi dalam bencana adalah masalah ketidakpastian.

Menurut Frank Dance (dalam Littlejohn dan Foss, 2006: 7), salah satu aspek penting di dalam komunikasi adalah konsep reduksi ketidakpastian. Komunikasi itu sendiri muncul karena adanya kebutuhan untuk mengurangi ketidakpastian, supaya dapat bertindak secara efektif demi melindungi atau memperkuat ego yang bersangkutan dalam berinteraksi secara indivuidual maupun kelompok. Dalam penanganan bencana, informasi yang akurat diperlukan oleh masyarakat maupun lembaga swasta yang memiliki kepedulian terhadap korban bencana.
Komunikasi bencana menjadi unsur krusial dalam upaya penanganan bencana. Saat terjadi bencana biasanya masyarakat membutuhkan informasi yang akurat, cepat dan tepat mengenai bencana tersebut. Sehingga persoalan mengenai informasi, komunikasi, juga koordinasi menjadi sangat penting untuk menangani korban bencana juga untuk menghindari terjadinya resiko selanjutnya. Keterlibatan stakeholder terkait baik itu kementerian atau lembaga terkait, badan usaha, media, juga masyarakat juga memegang peranan penting dalam komunikasi bencana, terutama dalam membantu meminimalisir resiko yang timbul akibat bencana tersebut.

Kita juga perlu memahami bahwa terdapat siklus yang harus diperhatikan dalam penanganan bencana yang mencakup situasi sebelum bencana, selama bencana dan setelah bencana. Sehingga kita perlu mempersiapakan langkah-langkah apa saja yang harus kita lakukan untuk menghadapi siklus-siklus tersebut. Komunikasi dalam bencana tidak saja dibutuhkan dalam kondisi darurat bencana, tapi juga penting pada saat dan pra bencana. Sebagaimana dikatakan bahwa komunikasi adalah cara terbaik untuk kesuksesan mitigasi bencana, persiapan, respon, dan pemulihan situasi pada saat bencana. Kemampuan untuk mengkomunikasikan pesan-pesan tentang bencana kepada publik, pemerintah, media dan pemuka pendapat dapat mengurangi resiko, menyelamatkan kehidupan dan dampak dari bencana (Haddow \& Haddow, 2009).

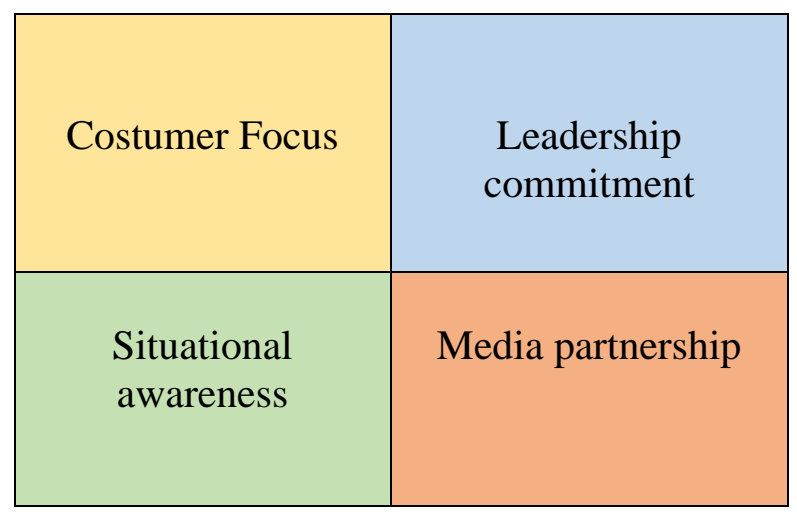

Gambar 3. Landasan Membangun Komunikasi Bencana

(Sumber: Haddow dan Haddow, 2009) 
Menurut Haddow dan Haddow (2009: 2) terdapat empat landasan utama dalam membangun komunikasi bencana yang efektif yaitu : Pertama, Costumer Focus, yaitu memahami informasi apa yang dibutuhkan oleh pelanggan dalam hal ini masyarakat dan relawan maka harus dibangun mekanisme komunikasi yang menjamin informasi disampaikan dengan tepat dan akurat, mengingat fokus pada pandemi Covid-19 di Indonesia ini meliputi komunikasi satu pintu, yang diharapkan kedepannya komunikasi ini efektif tidak membingungkan masyarakat luas khususnya rakyat Indonesia. Kedua, Leadership commitment, pemimpin yang berperan dalam tanggap darurat harus memiliki komitmen untuk melakukan komunikasi efektif dan terlibat aktif dalam proses komunikasi. Ketiga, Situational awareness, komunikasi efektif didasari oleh pengumpulan, analisis dan diseminasi informasi yang terkendali terkait bencana. Prinsip komunikasi efek-tif seperti transparansi dan dapat di-percaya menjadi kunci. Keempat, Media partnership, media seperti televisi, surat kabar, radio, dan lainnya adalah media yang sangat penting untuk menyampaikan informasi secara tepat kepada publik. Kerjasama dengan media menyangkut kesepahaman tentang kebutuhan media dengan tim yang terlatih untuk berkerjasama dengan media untuk-mendapatkan informasi dan menyebar-kannya kepada publik.

Penanggulangan bencana, harus didukung dengan berbagai pendekatan baik soft power maupun hard power untuk mengurangi resiko dari bencana. Pendekatan soft power adalah dengan mempersiapkan kesiagaan masyarakat melalui sosialisasi dan pemberian informasi tentang bencana. Sementara hard power adalah upaya menghadapi bencana dengan pembangunan fisik sepeti membangun sarana komunikasi, membangun tanggul, mendirikan dinding beton, mengeruk sungai dan lain-lain. Dalam UU, dua hal ini yang disebut mitigasi bencana, pada dua pendekatan inilah, komunikasi bencana amat dibutuhkan.

Dalam UU No 23 Tahun 2007 tentang Penanggulangan Bencana, salah satu langkah yang penting dilakukan untuk pengurangan resiko bencana adalah melalui mitigasi bencana. Dijelaskan mitigasi bencana adalah serangkaian upaya untuk mengurangi resiko bencana, baik melalui pembangunan fisik maupun penyadaran dan peningkatan kemampuan menghadapi ancaman bencana. Salah satu bentuk kegiatan mitigasi bencana menurut pasal 47 ayat 2 (c) adalah melalui pendidikan, penyuluhan dan pelatihan baik secara konvensional maupun modern.

Untuk mengintegrasikan karakter masyarakat kawasan rawan bencana dengan regulasi pemerintah dalam penanganan bencana, bisa tercapai dengan baik jika kedua belah pihak mampu menciptakan komunikasi kohesif yang menghasilkan pemahaman bersama. Namun persoalannya dalam kondisi darurat bencana, membuka sinyal komunikasi untuk menangani korban dengan cepat, tidak mudah untuk dilaksanakan, sebab lembaga pemerintah dibelenggu oleh belantara peraturan, sedangkan masyarakat selain tetap berpijak kepada nilai setempat, juga dikuasai oleh pesan-pesan dari sumber yang tidak jelas nilai faktualnya (Budi, 2011: 17).

\section{Model Komunikasi Bencana}

Salah satunya penelitian yang dilakukan Jeanne Branch Johsnton dari University of Hawaii dengan judul Personal Account From Survivor of the Hilo Tsunamis 1946 and 1960: Toward A Dister Communication Models. Penelitian ini dilakukan untuk mengetahui pengakuan personal para korban selamat dari bencana tsunami di Hilo pada tahun 1946 dan 1960. Penelitian ini menemukan bahwa pada bencana tsunami di Hilo tahun 1946 dan 1960 terjadi kesalahan prosedur dan koordinasi pemerintah dalam mengantisipasi bencana tsunami. Pihak berwenang dalam hal ini dinas pertahanan sipil, kepolisian di Hawaii dan Hilo mengalami miskomunikasi dan koordinasi sehingga pemberitahuan kepada warga Hilo terlambat diberitakan. Selain itu ditemukan juga bahwa media massa melakukan kesalahan dalam menyampaikan berita kepada publik tentang tsunami. Media menyampaikan berita 
melalui radio di Hawaii bahwa tidak akan ada gelombang tsunami dalam satu jam ke depan. Masyarakat juga diketahui memiliki pengetahuan yang sangat rendah tentang bencana tsunami. Hal itulah yang dianggap menjadi salah satu sebab banyaknya korban yang tewas pada dua bencana alam tersebut (Johnston, 2013). Lalu pertanyaan yang sering muncul dalam konteks Misscommunication tersebut adalah bagaimana penggunaan komunikasi dalam upaya membantu pemulihan masyarakat korban bencana (Healy dan Wahlen, 1998).

Melihat hal tersebut maka, model komunikasi bencana harus segera di tetapkan oleh pemerintah ketika bencana itu terjadi untuk menghindari segala kemungkinankemungkinan buruk yang bisa saja menimpa masyarakat, olehkarnanya KOMINFO melakukan tanggap bencana dengan model komunimasi bencana yang meliputi antara lain, Informasi, Komunikasi, Koordinasi, Mitigasi bencana dan media.

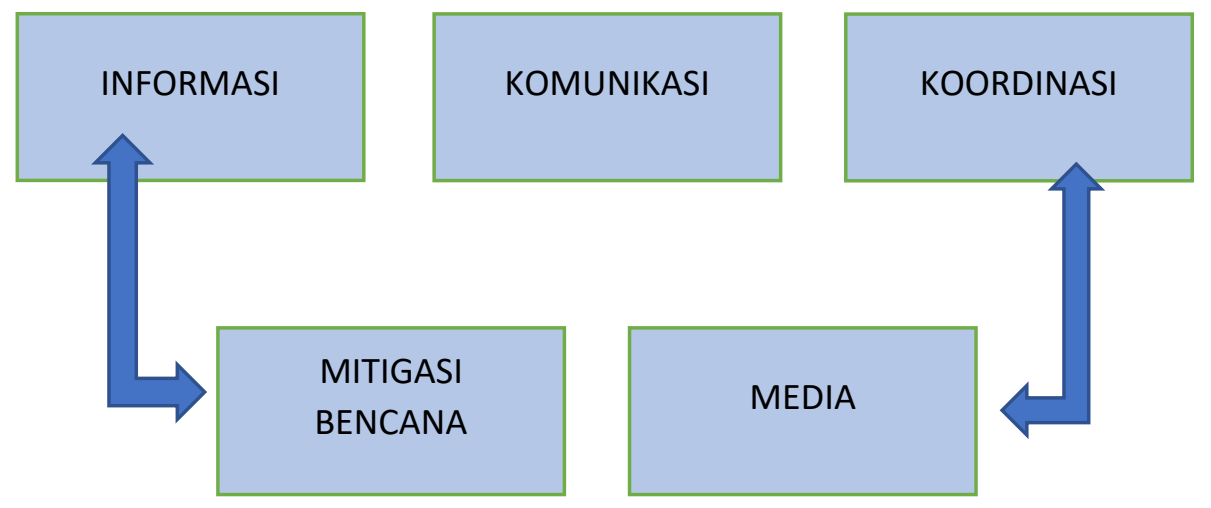

Gambar 4. Model Komunikasi Bencana Kominfo

(Sumber: Hasil Olahan Penulis, 2020).

Model Komunikasi bencana yang diterapkan oleh KOMINFO terkait akan lima hal yaitu, Informasi, Komunikasi, Koordinasi, Media dan Mitigasi Bencana menjadi kunci sukses dalam penanganan bencana, khususnya dalam penanganan korban dan menghindari hadirnya resiko lebih lanjut. Selain itu mitigasi bencana juga diperlukan untuk memastikan pencegahan dan pengurangan resiko dengan melibatkan berbagai stakeholder termasuk masyarakat.

Informasi. Informasi, komunikasi dan koordinasi menjadi kunci sukses dalam penanganan bencana, khususnya dalam penanganan korban dan menghindari hadirnya resiko lebih lanjut. Selain itu mitigasi bencana juga diperlukan untuk memastikan pencegahan dan pengurangan resiko dengan melibatkan berbagai stakeholder termasuk masyarakat. Selain itu keterlibatan media juga penting dalam menyebarkan informasi terkait kebencanaan. Kita harus memastikan pesan dan informasi yang disampaikan media akurat, cepat dan tepat sehingga tidak terjadi kebingungan dan kepanikan di masyarakat. Media diharapkan bisa membantu pemerintah dalam mengedukasi masyarakat dan mengurangi resiko yang bisa timbul di masyarakat akibat suatu bencana. Hal lainnya yang tidak kalah penting adalah bagaimana pemerintah mampu meningkatkan tingkat literasi digital, agar masyarakat tidak secara serta merta menerima informasi yang beredar tanpa memeriksa terlebih dahulu kebenaran berita tersebut (Setu, 2020).

Komunikasi. Komunikasi dalam hal ini adalah adanya protokol komunikasi publik saat terjadi bencana, begitu juga pemilihan saluran media apa yang akan digunakan. Komunikasi publik ini sangat penting karena saat terjadi 
bencana, masyarakat membutuhkan informasi yang akurat, cepat dan tepat untuk menghindari kepanikan. Apalagi saat ini informasi dapat menyebar dengan cepat, sehingga perlu dibarengi dengan tingkat melek literasi yang tinggi juga, sehingga masyarakat mampu membedakan mana informasi yang benar dan tidak benar. Selain itu, kita juga perlu mempersiapkan berbagai langkah penanganan bencana mulai dari sebelum bencana, selama bencana dan setelah bencana. Sehingga ketika terjadi lagi bencana yang sama atau menyerupai kita sudah memiliki antisipasi dalam menangani bencana tersebut.

Koordinasi. Keterlibatan stakeholder dalam penangan bencana sangat diperlukan, guna menyambung komunikasi yang disampaiakan oleh pusat agar bisa menyebar efektif ke setiap lapisan masyarakat, peran opinion leader juga sangat penting dan dibutuhkan dalam komunikasi bencana Covid19. Hal ini dikarenakan masih banyak masyarakat yang minim akses dalam mendapatkan informasi melalui media massa, media online juga media sosial. Sehingga disini opinion leader bisa mengambil peran dalam menyebarkan informasi penting terkait Covid19.

Kita beberapa kali melihat di media ada keluarga pasien yang positif Covid-19 nekat membawa paksa jenazah pasien tersebut. Hal ini menunjukan bahwa informasi mengenai Covid-19 ini masih minim, sehingga masyarakat tidak mengetahui protokol dalam penanganan jenazah pasien Covid-19. Selain itu pemahaman masyarakat tentang social distancing, jaga jarak,dan lockdown juga masih minim. Untuk itu, dalam upaya menangani krisis akibat Covid-19 ini kita perlu melibatkan opinion leader pada suatu komunitas bisa pemuka agama, tokoh masyarakat juga warga yang dituakan dan para ketua RT/RW untuk ikut berperan aktif menjadi kepanjangan tangan pemerintah dalam mengedukasi masyarakat mengenai berbagai informasi terkait Covid-19. Peran opinion leader ini sangat dibutuhkan agar informasi dapat sampai kepada masyarakat dan di beberapa tempat dan kondisi, masyarakat biasanya akan lebih mudah percaya dengan opinon leader yang dianggap memilki kesamaan dengan meraka.

Media. Keterlibatan media dinilai penting dalam menyebarkan informasi terkait kebencanaan. Kita harus memastikan pesan dan informasi yang disampaikan media akurat, cepat dan tepat sehingga tidak terjadi kebingungan dan kepanikan di masyarakat. Media diharapkan bisa membantu pemerintah dalam mengedukasi masyarakat dan mengurangi resiko yang bisa timbul di masyarakat akibat suatu bencana. Bagaimana pemerintah mampu meningkatkan tingkat literasi digital agar masyarakat tidak secara serta merta menerima informasi yang beredar tanpa memeriksa terlebih dahulu kebenaran berita tersebut.

$$
\text { Mitigasi Bencana. Aplikasi }
$$

PeduliLindungi adalah aplikasi yang digagas oleh Kementerian Komunikasi dan Informatika dan Kementerian BUMN dengan kordinasi Gugus Tugas Covid-19, Badan Nasional Penanggulangan Bencana (BNPB), Kementerian Kesehatan, Kementerian Pendayagunaan Aparatur Negara dan Reformasi Birokrasi, serta TNI dan Polri. Aplikasi PeduliLindungi ini dipergunakan dalam pelaksaanaan surveilans kesehatan oleh pemerintah dalam menangani penyebaran Covid-19 antara lain berupa penelusuran (tracing), pelacakan (tracking) dan pemberian peringatan (warning dan fencing).

$$
\text { Seperti diketahui, aplikasi }
$$

PeduliLindungi memiliki fitur aplikasi tracking yang dapat mendeteksi pergerakan terpapar Covid-19 selama 14 hari ke belakang. Aplikasi ini juga dapat terhubung dengan operator selular lainnya untuk menghasilkan visualisasi yang sama. Berdasarkan hasil tracking dan tracing nomor di sekitar pasien positif Covid19 yang terdeteksi akan diberikan peringatan untuk segera menjalankan protokol kesehatan. Aplikasi ini juga digunakan untuk memonitor pendatang dari luar negeri dan pos lintas batas.

Selain itu aplikasi PeduliLindungi juga terintegrasi dengan sistem Bersatu Lawan Covid-19, Pusat Data dan Informasi 
Kementerian Kesehatan, Rumah Sakit BUMN, klinik di bawah Telkomedika, layanan digital healthcare dengan Halodoc, Prixa, BPPT, ProSehat dan digital startup dengan OVO dan Gojek. Aplikasi PeduliLindungi ini bekerja untuk kepentingan masyarakat, sehingga semakin banyak masyarakat yang memasang dan menggunakannya smartphone maka tingkat akurasinya akan semakin tinggi, sehingga kita dapat membantu sesama dalam menanggulangi penyebaran Covid-19, yang diharapkan mampu menjadi salahsatu media mitigasi bencana ditengah pandemi Covid-19 yang belum berakhir di tanah air.

\section{Fungsi Media Sosial dalam Komunikasi Bencana}

Penelitian dengan judul Best Practices: The Use of Social Media Throughout Emergency \& Disaster Relief dilakukan oleh Erica Goldfine dari American University pada tahun 2011. Risetnya dilakukan dengan tujuan untuk mengetahui bagaimana penggunaan media sosial pada saat darurat bencana. Penelitian ini mengambil lembaga-lembaga sosial peduli bencana sebagai subjek penelitian antara lain Direct Relief Internation-al, Chatolic Medical Mission Board, Humani-tarian Information Unit, Office of the Assistant Secretary for Preparedness and Response dan World Vision Program. Metode penelitian yang digunakan adalah penekatan kualitatif dengan metode wawancara mendalam tak berstruktur. Informan yang diwawancarai adalah para operator komunikasi sebanyak enam orang dari masing-masing lembaga. Dipilihnya operator komunikasi ini karena dianggap memiliki pemahaman dan pengalaman tentang pemanfaatan media sosial di lembaganya selama masa darurat dan pemulihan bencana.

Penelitian ini menyimpulkan bahwa belajar dari pengalaman yang ada, pemanfaatan media sosial dapat memaksimalkan kegiatan penanggulangan darurat dan pemulihan bencana. Kemudian media sosial yang digunakan dalam penanganan bencana baiknya adalah media yang populer dan relevan dengan penggunaan masyarakat. Selanjutnya penggunaan media sosial juga dapat memudahkan pemetaan dan mengetahui lokasi bencana. Terakhir penggunaan media sosial secara tepat akan bermanfaat untuk pemulihan bencana (Goldfine, 2011).

\section{SIMPULAN}

Berbagai peristiwa bencana Covid-19 yang melanda dunia dan terutama Indonesia terlihat semakin menunjukkan jumlah dan dampak yang begitu membesar. Proses manajemen bencana menjadi amat sangat diperlukan untuk pengurangan resiko bencana tersebut, untuk hal ini, pemahaman mengenai siklus dan pendekatan manajemen bencana. model komunikasi bencana harus segera di tetapkan oleh pemerintah ketika bencana itu terjadi untuk menghindari segala kemungkinan-kemungkinan buruk yang bisa saja menimpa masyarakat, oleh karnanya KOMINFO melakukan tanggap bencana dengan model komunikasi bencana yang meliputi antara lain, Informasi, Komunikasi, Koordinasi, Mitigasi bencana dan Media. Keterlibatan media juga penting dalam menyebarkan informasi terkait kebencanaan memastikan pesan dan informasi yang disampaikan media akurat, cepat dan tepat sehingga tidak terjadi kebingungan dan kepanikan di masyarakat. Media diharapkan bisa membantu pemerintah dalam mengedukasi masyarakat dan mengurangi resiko yang bisa timbul di masyarakat akibat suatu bencana.

Hal lainnya yang tidak kalah penting adalah bagaimana pemerintah mampu meningkatkan tingkat literasi digital, agar masyarakat tidak secara serta merta menerima informasi yang beredar tanpa memeriksa terlebih dahulu kebenaran berita tersebut. Aplikasi PeduliLindungi diciptakan oleh pemerintah sebagai bagian dari mitigsi bencana Covid-19 di Indonesia, diharapkan aplikasi ini mampu untuk mengidentifikasi orang-orang yang pernah berada dalam jarak dekat dengan orang yang dinyatakan positif Covid-19 atau Pasien Dalam Pengawasan (PDP) dan Orang Dalam Pengawasan (ODP). Melalui aplikasi tersebut, pengguna dapat mengingat riwayat 
perjalanan dan dengan siapa saja dia melakukan kontak. Selain itu, aplikasi ini juga dapat memudahkan masyarakat yang tengah beraktivitas di luar rumah untuk mewaspadai kurir pembawa virus. Pada kenyataannya pengunduh aplikasi PeduliLindungi masih terlalu kecil sehingga dibutuhkan peran aktif masyarakat untuk bersama-sama memanfaatkan aplikasi PeduliLindungi ini. Selain itu diperlukan juga enforcement dari pemerintah untuk terus meningkatkan efektivitas dari aplikasi ini juga mendorong pihak-pihak terkait untuk dapat memaksimalkan fungsi dari aplikasi PeduliLindungi ini.

\section{DAFTAR PUSTAKA}

Ali, U. (2015). Teknik pengumpulan dan analisis data kualitatif. Pengertian Pakar. Retrieved January 10, 2020, from

http://www.pengertianpakar.com/2015/ 05/teknik-pengumpulan-dan-analisisdata-kualitatif.html

Budi HH, S. (2012). Komunikasi Bencana: Aspek Sistem (Koordinasi, Informasi dan Kerjasama). Jurnal ASPIKOM, l(4), 362-372. doi:http://dx.doi.org/10.24329/aspikom .v1i4.36

Budi HH, S. (ed). (2011). Komunikasi Bencana. Yogyakarta: Asosiasi Pendidikan Tinggi Ilmu Komunikasi (ASPIKOM).

Goldfine, E. (2011). Best Practices: The Use of Social Media Throughout Emergency \& Disaster Relief. Master's Projects.

Haddow, G. D. \& Haddow, K. S. (2009). Disaster Communications Changing Media World. United States of America: Elseiver Inc.

Healy, P. M. and Wahlen, J. M. (November 1998). A Review of The Earnings Management Literature And Its Implications For Standart Setting. https://dx.doi.org/10.2139/ssrn.156445

Johsnton, J. B (2003). Personal Account From Survivor of the Hilo Tsunamis 1946 and
1960: Toward A Dister Communication Models. University Of Hawaii Library. Lestari, P., Ritonga, R., Ruliana, P., \& Barus, C. C. Br. (2020). Disaster Communication Uses Field Training Exercise Simulation as an Important Aspect of Disaster Risk Reduction. Jurnal Komunikasi: Malaysian Journal of Communication, 36(1), 166-186. https://doi.org/10.17576/JKMJC-20203601-10

Littlejohn, S. W. \& Foss, K. A. (2009). Teori Komunikasi: Theories of Human Communication. Terjemahan. Jakarta: Penerbit Salemba Humanika.

Mulyana, D. (2007). Ilmu Komunikasi: Suatu Pengantar. Bandung: Remaja Rosdakarya.

Pahleviannur, M. R. (2019). Edukasi Sadar Bencana Melalui Sosialisasi

Kebencanaan Sebagai Upaya

Peningkatan Pengetahuan Siswa Terhadap Mitigasi Bencana. Jurnal Pendidikan Ilmu Sosial, 29(1), 49-55. http://dx.doi.org/10.23917/jpis.v29i1.8 203

Permana, R. C. E., Nasution, I. P., \& Gunawijaya, J.(2011). Kearifan Lokal Tentang Mitigasi Bencana pada Masyarakat Baduy. Makara Seri Sosial Humaniora, 15(1), 67-76. DOI:10.7454/mssh.v15i1.954

Rahman, A. Z. (2015). Kajian Mitigasi Bencana Tanah Longsor di Kabupaten Banjarnegara. Gema Publica: Jurnal Manajemen dan Kebijakan Publik, 1(1), 1 -

14. https://doi.org/10.14710/gp.1.1.201 5.1-14

Ruben, B. D. \& Stewart, L. P. (2013). Komunikasi dan Perilaku Manusia. Jakarta: Rajawali.

Rusilowati, A. Supriyadi, Binadja, A., \& Mulyani, S. E. S. (2012). Mitigasi Bencana Alam Berbasis Pembelajaran Bervisi Science Environment Technology and Society. Jurnal Pendidikan Fisika Indonesia, 8(1), 51- 
JURNAL PUSTAKA KOMUNIKASI, Volume 4, No. 1, Maret 2021, hlm 66-78

60.

http://dx.doi.org/10.15294/jpfi.v8i1.19

94

Setu, F. (12 Agustus 2020). Wawancara

Pribadi. 